\title{
STRAKS WEER TE ZIEN IN HET RIJKSMUSEUM Een jaden cong
}

De vormen van het Paviljoen voor Aziatische kunst zijn inmiddels in beton gegoten en het is bijzonder om door de ruimtes te kunnen lopen die straks museumzalen zullen zijn. Om u een indruk te geven van wat er straks op zaal te zien zal zijn, is dit een goed moment om een nieuwe reeks van kleine artikelen te beginnen. De selectie van wat getoond zal gaan worden is afgerond en er wordt nu hard gewerkt aan het schrijven van alle teksten en het vervolmaken van de details van de vitrines. Tot de opening in $2013 \mathrm{zal}$ in Aziatische Kunst aandacht worden besteed aan een voorwerp uit de nieuwe opstelling.

Wellicht is het passend om de reeks te beginnen met het oudste stuk uit de collectie, een Chinese jade cong (afb. 1). Een intrigerend voorwerp, zeker als we ons realiseren hoe oud hij is: meer dan 4000 jaar. Anders gezegd in Europese termen, meer eeuwen voor het begin van onze jaartelling dan wij nu erna leven. Hij dateert uit de tijd voordat in China het schrift was ontstaan en er zijn dan ook geen bronnen die ons kunnen vertellen waar hij precies voor diende, of zelfs maar hoe het voorwerp heette. De benaming cong komt voor het eerst voor in geschriften uit de late Zhou-periode (770-221 v.Chr.) - 2000 jaar na de tijd van vervaardiging - waardoor het niet erg waarschijnlijk is dat de theorieën die toen werden opgeschreven betrouwbaar zijn.

Hoe dan ook, het moet een belangrijk voorwerp zijn geweest, want het bewerken van jade was erg moeilijk en tijdrovend. Jade is veel harder dan metaal. Het kon niet worden gesneden, maar moest worden bewerkt met boren of zagen en worden geslepen met schuurmiddelen zoals zand. Bij de grote modellen zoals ons exemplaar van meer dan 30 centimeter was het een ingewikkelde klus om het stuk jade over de hele lengte uit te hollen. In dit geval is het niet helemaal gelukt om de boorgaten die aan beide kanten zijn gemaakt in het midden precies op elkaar te laten aansluiten. Hoe dan ook, het vereiste specialisten die dit langdurige, technisch hoogstaande werk konden verrichten. Gezien de grote aantallen die in graven werden meegegeven moet het een industrie van enige omvang zijn geweest, die functioneerde in een maatschappij van verschillende standen. Immers, er moet een elite zijn geweest die het zich kon veroorloven om de werklieden aan te stellen voor het maken van kostbare voorwerpen, waarvan het de vraag is of ze wel enig praktisch nut hebben gehad.

Er zijn veel speculaties over de functie van cong. De versiering van gestileerde gezichten op de hoeken (afb. 2) zouden van een diermasker kunnen zijn, terwijl er op sommige exemplaren ook mensachtige figuren zijn afgebeeld, die de ogen van een monsterachtige kop vasthouden. Dit doet denken aan bovennatuurlijke wezens in een religieuze context, maar eigenlijk Kunnen we er: $18: 54 \mathrm{Am}$ 

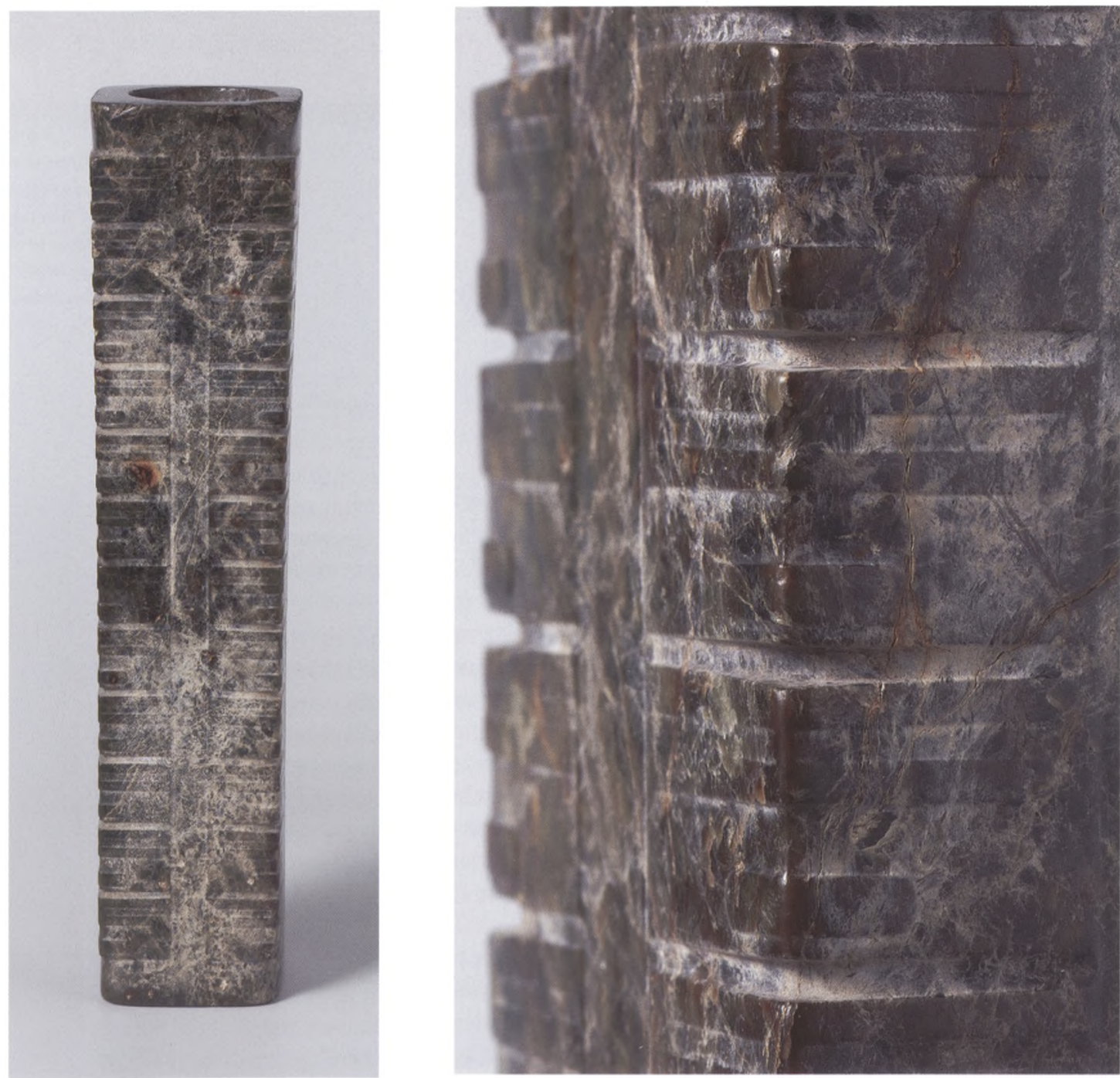

Afb. I (links)

Cong, jade, h. $32,5 \mathrm{~cm}$.,

China, 3000-2000

v.Chr., Rijksmuseum,

langdurig bruikleen

Vereniging van Vrienden

der Aziatische Kunst,

inv.nr. AK-MAK-51.

Afb. 2

Hoekversiering van

gestileerde gezichten

op de cong niets met zekerheid over zeggen. Uit opgravingen weten we dat ze in graven werden meegegeven, liggend langs het lichaam. De aanwezigheid van zulke grote aantallen kostbare voorwerpen wijst in ieder geval op een hoge status van de overledene en het moeten hoe dan ook belangrijke voorwerpen zijn geweest.

In de opstelling zult $u$ dit voorwerp straks in de benedenzaal van het Paviljoen kunnen bezichtigen. Hier komt een fraaie, lange wandvitrine die de collectie Chinese voorwerpen in min of meer chronologische volgorde toont, uiteraard te beginnen met de enigmatische cong. 